https://helda.helsinki.fi

Tellability, frame and silence : the emergence of internment memory

Savolainen, Ulla

2017

Savolainen , U 2017 , ' Tellability, frame and silence : the emergence of internment memory '

, Narrative Inquiry , vol. 27 , no. 1, pp. 24-46 . https://doi.org/10.1075/ni.27.1.02sav

http://hdl.handle.net/10138/211423

https://doi.org/10.1075/ni.27.1.02sav

acceptedVersion

Downloaded from Helda, University of Helsinki institutional repository.

This is an electronic reprint of the original article.

This reprint may differ from the original in pagination and typographic detail.

Please cite the original version. 
This is a post-print of an article published in Narrative Inquiry 27:1(2017), 24-46. DOI: $10.1075 /$ ni.27.1.02sav issn 1387-6740 / e-issn 1569-9935 ㅇ John Benjamins Publishing Company

\title{
Tellability, frame and silence
}

\section{The emergence of internment memory}

\author{
Ulla Savolainen, $\mathrm{PhD}$ \\ University of Helsinki, Folklore Studies / LIVINGMEMORIES-project
}

\begin{abstract}
On the basis of the September 1944 Moscow Armistice agreement between Finland, the Soviet Union and the UK, the Finnish government was obliged to intern German and Hungarian citizens in Finland. Applying the concepts of "tellability" and "frame", I examine how individuals (most of them children of German fathers and Finnish mothers) who were interned as minors and young people in Finland in 1944-1946 describe silence and the rupture of silence. In order to understand the interaction and dynamics between individuals' remembering and public memory, I analyze oral history interviews of ex-internees in relation to public discussion. I argue that bringing together viewpoints of narrative analysis, oral history research and memory studies facilitates understanding of the link between the individual, private and public dimensions of memory construction. Furthermore, I suggest that the analytical concepts of tellability and frame are highly useful in understanding why some experiences and events of the past are narrated and remembered while others are forgotten or silenced.
\end{abstract}

Keywords: tellability, frame, oral history, memory studies, internment, the Second World War

\section{Introduction}

In 2003, the Finnish public service broadcasting company Yle broadcast a documentary film by the journalist Mikko Määttälä entitled 'Finland of Prison Camps' (Vankileirien Suomi). The film was about the internment of German and Hungarian citizens, most of whom were civilians, in Finland in 1944-1946. The internment was based on the conditions of the September 1944 Moscow Armistice 
between Finland, the Soviet Union and the United Kingdom. The documentary film revealed that the internment not only concerned German and Hungarian men living in Finland, but also their spouses (often Finnish-born women) and children. At the time of the documentary broadcast, hardly anyone in Finland, despite the ex-internees themselves, knew about this internment. Indeed, the event had been almost totally absent from public discussion, academic research (exc. JensenEriksen, 2000) and the historical consciousness of Finns. The documentary also included information that came as a surprise for the ex-internees. The film revealed that the incarceration of Finnish-born women and children was based on the decision of Finnish officials. Until then, the ex-internees had believed that their internment was ordered by the Soviet Union, but now they learned that their own country was responsible. Mikko Määttälä's documentary set in motion a process of public awareness about the historical event of internment which included a research project on the topic (Westerlund (ed.), 2010; Jensen-Eriksen, 2009), a published book (Määttälä, 2011) and media discussions. This process eventually led to the enactment of compensatory legislation on September 1, 2014 (Finlex Data Bank, 2014).

In this article, I focus on descriptions of silence and the rupturing of silence related to the German and Hungarian citizens' internment in Finland in 1944-1947. I will analyze how ex-internees narrate about silence and silencing in the postinternment decades, and how they reflect the silence that occurred both on a personal level (as a practice of silencing) and on a societal level (as the absence of the topic of internment in public discussion and historical consciousness). I will analyze descriptions of how interviewees communicated - if they communicated their experience of internment to their family members and others who were not at the camps. In addition, I will examine how my interviewees reflect the emergence of public discussion of the internment. I will apply the concepts of "tellability" and "frame" to analyze how ex-internees describe the silence and the breaching of silence, and I will explore the interaction and dynamics between individuals' remembering and public memory. I will argue that in terms of constructing the memory of internment, the public and personal dimension of memory creation are mutually dependent (see Hamilton \& Shopes, 2008; Thomson, 1996). I will also claim that the emergence of memory is vitally connected to the tellability of the story (see Shuman, 2006, 2012; Norrick, 2005; Ochs \& Capps, 2001) and frames, which guide and are used in the perception, reception and representation of the experience (see Goffman, 1974; see also van Vree, 2013). Hence, I will show how 
analytical concepts of tellability and frame can be used in understanding the dynamics between personal and public memory, and in understanding why some experiences and events of the past are narrated and remembered while others are forgotten or silenced. By way of narrative/conversation analysis, my aim is also to bring the scopes of oral history research and memory studies into a fruitful dialogue.

My primary research materials consist of oral accounts of individuals, most of them children of German fathers and Finnish mothers, ${ }^{1}$ who were interned as minors in Finland in 1944-1946. I conducted 26 oral history interviews in Finland and in Germany ${ }^{2}$ during 2015-2016, as well as ethnography related to this oral history fieldwork. ${ }^{3}$ The interview language was Finnish. The persons I interviewed were born between 1926 and 1943. Hence, they were between 1 and 18 years of age when the internment began. In terms of gender, 14 of the interviewees were women and 12 of them were men. The majority of these interviews ( 24 total) were audio-recorded and later transcribed by me. ${ }^{4}$

I will use the concept of tellability in a broad and metaphorical way by extending the concept beyond a certain text and an actual situation of telling (the interview situation). I will use the concept of tellability to examine why and how the historical event and experience of internment was untellable or silenced in the succeeding decades and why and how it became tellable later. Additionally, my

1 The majority of the internees were of German background: 23 of my interviewees had German

${ }^{2}$ Only one interview was conducted in Germany.

${ }^{3}$ During my research, I was able to visit the homes of many of the interviewees. In addition to recorded interviews, these meetings included discussions that were not taped. Interviewees often also showed me memorabilia and documents related to the internment, such as drawings, paintings, photographs, letters, newspaper articles and mementos. Some persons had also written (unpublished) memoirs, and I was able to get permission to use these works as research material. During my fieldwork, I photographed visual research materials, mostly mementos related to the internment or other significant moments in the persons' lives, and I recorded my observations in my field diary.

4 The lengths of the interview recordings vary between 45 minutes and 165 minutes. I asked the interviewees for consent to deposit the interview tapes in the Archives of the Finnish Literature Society after my research, and most of the interviewees agreed to this. Two of the interviews were not recorded on tape. The reasons why these two interviews were not recorded are following: one of them was a telephone conversation and the other took place in a car while driving from place to place. 
aim is to identify frames which are closely connected to the tellability of the story. I understand frames as cognitive structures guiding the perception and representation of experience.

I will begin this article by introducing the historical context of internment and by reviewing theoretical notions related to memory, silence, frames and tellability. Then I will move to my empirical analysis. First, I examine the reasons for the silence and the lack of a frame by discerning the ways in which the interviewees described the silence. By doing this, I explore why the story of internment was untellable for a long time. Second, I explore why and how the silence was ruptured, how the frame emerged and ultimately why the story of internment became tellable. Through my analysis, I will show that the levels of personal and public memory are interconnected, and thus, why they should be analyzed in relation to each other.

\section{History of the internment}

During the Second World War, Finland fought two wars (the Winter War in 19391940 and the Continuation War in 1941-1944) against the Soviet Union. In the latter, Finland was unofficially allied with Nazi Germany. After the hostilities between Finland and the Soviet Union ended in August of 1944, the two countries signed the Armistice agreement in Moscow on September 19, 1944. The conditions of the armistice agreement were harsh. Finland had to cede areas in Eastern Finland to the Soviet Union as well as pay extensive reparations to the Allied forces. In addition, Finland was obliged to banish German troops from its territory and intern all of the German and Hungarian citizens in Finland. This led to the incarceration of 470 civilians in 1944-1946. In addition to German and Hungarian men, the Finnish officials also decided to intern their Finnish-born spouses and children in October 1944. Due to marriage, these women and children were technically German/Hungarian nationals or had dual citizenship. (JensenEriksen, 2009, pp. 24-41; 2010, pp. 133-134.)

According to A Dictionary of Human Rights, internment usually means:

detention of those either suspected, but not proved, to be guilty of crimes, or thought to have a high probability of being likely to commit crimes even if they are not currently even suspected of having done so. As such, a policy of 
internment is in flagrant violation of the core human right of liberty of the person, which almost all constitutional codes protect. Internment, by its very nature, involves a denial of due process and all associated rights, including that to a fair trial. (Robertson (ed.), 2004, p. 130 [original emphasis])

Internment as a concept in international law has its origins in the Brussels Conference of 1887 , which sought to achieve a pact on the customs and laws of war. Later, the principles of internment were defined in the Hague Convention of 1907 and the Geneva Convention of 1929. In these conventions, however, nothing was actually said about the internment of civilians, even though Section III of the Hague Convention of 1907 discusses the authority of occupying forces over civilians. Despite the lack of a proper international agreement on the detention of civilians, the twentieth century with its various conflicts became an age of concentration and forced labor camps, mass internments and deportations, not only of prisoners of war but also civilians, including both foreigners and citizens (Robertson (ed.), 2004, p. 130; Westerlund, 2008b, pp. 353, 355, 384; see also Westerlund (ed.), 2008a; on terminology, Schiffrin, 2001). In addition to Nazi concentration camps and the Soviet Union's Gulag camps (see e.g. Toker, 2000, pp. 11-27; Khevniuk, 2004) for example, roughly 110,000 Japanese Americans were interned in the U.S. during the WWII after the Japanese attack on Pearl Harbor (see e.g. Smith, 1995; Schiffrin, 2001). It is estimated that approximately 162,000 persons were interned in Finland during WWII (Westerlund, 2008b, p. $385)$.

As we can see, the internment of citizens or aliens (especially citizens of enemy countries) is not unusual during times of war. Most of the persons interned in Finland in 1944-1946 did not have any military importance or criminal background. Internees were mainly women, children, elderly persons and other politically or militarily insignificant persons. Many of them were secondand thirdgeneration immigrants or their Finnish-born spouses or children without any political connections to Nazi Germany. They were highly integrated and assimilated into Finnish society, and as a group, they were not discriminated or prejudiced. This is probably one of the most significant differences between internment of Germans and Hungarians in Finland and internment of JapaneseAmericans in the U.S. (see Schriffin, 2001, pp. 513-514). Almost all of those Germans in Finland who had actual connections to Hitler's Nazi Germany left the country when Finland made peace with the Allied forces, at the latest. Some German citizens also moved to Sweden (Jensen-Eriksen, 2009, 2010). 
The internment camps in Finland were administrated by the Valpo, the Finnish security police. The living conditions in the internment camps cannot be considered similar to those in German or Soviet labor and concentration camps (see also Schiffrin, 2001). In Finland, guards or officials did not abuse or torture internees, and internees were entitled to medical care when it was needed. Indeed, almost all of the persons whom I interviewed emphasized that life at the internment camps was actually quite nice from the perspective of a child. Many of them remember that the guards, who were typically young men performing their military service, were friendly and sympathized with their situation. Many of my interviewees told me how easy it was for children to sneak under the camp fences to go pick berries, for example. Some interviewees were also able to continue their school studies. Some were allowed to take their exams at school, although accompanied by an armed guard. Internees were given meals at the camps, but the quality of food was not adequate due to the general shortage in Finland. In fact, disgusting or otherwise strange food is the most often repeated motif found in my research material, and it is often followed by a comment that bad food was not uncommon during wartime; hence, bad camp food was not intended as deliberate torture or punishment. Due to the lack of proper food, some of the interned children became malnourished and were allowed to stay temporarily with their relatives in the countryside where they could get better nutrition. Although the interviewees typically highlighted that they did not suffer at the camps, they also stressed that their parents did. Interviewees also often stated that their parents' discomfort affected the children. Interviewees described how the uncertainty of the future - the pain of not knowing what would happen next or how long the internment would last - tormented their parents. The fear of being sent off to Siberia was very often mentioned by the interviewees (see also Jensen-Eriksen, 2010; Uhlenius, 2010; Määttälä, 2011).

The majority of internees were freed in March 1946, ${ }^{5}$ and most of them continued their lives in Finland, eventually gaining Finnish citizenship. In my research

\footnotetext{
${ }^{5}$ Fifteen internees, allegedly fanatic fascists, were not freed in March 1946. They were deported from Finland in the summer of 1947. The historian Niklas Jensen-Eriksen has stated that these persons were hardly fanatic or fascists. Instead they were right-wing Finns (which was common at the time) who were not accused of warcrimes or any other crimes. The acquisitions were based on the reports of one internee who worked for the (at that time, Communist) Finnish Security Police (Jensen-Eriksen, 2009, pp. 46-56).
} 
materials, the period after internment is described as being more difficult than the time of the actual internment. Many of my interviewees described how it was impossible for the internees to return to their former lives afterwards. The main reason for this was that the property of German and Hungarian citizens was confiscated and handed over to the Soviet Union. After the internment, silence occurring in public and often also on private and personal levels - descended over the topic for almost sixty years.

\section{Silence, tellability and frames}

Silence has intrigued scholars of the two main research fields focusing on cultural and social aspects of memory, namely cultural memory studies and oral history research. The main difference between these two branches of research is their divergent scales of viewpoint towards memory. Oral history research focuses on the role of memory in the lives and practices of persons and small communities, and it understands memory as a communicative resource transmitted through interaction between individuals. The focus of oral history research has included grassroots perspectives on history and the voices of individuals who represent "folk" (opposed to the perspectives of a state, country, continent, or those with power or status). Oral history research is characterized by the dialogic production of research materials, namely oral history interviews. Oral history research also focuses on present-day interpretations and meanings given to the past, and the narrative form of the oral testimonies (Portelli, 1998; Abrams, 2010; Hamilton \& Shopes, 2008, pp. viii-ix). Cultural memory studies, on the other hand, analyzes memory as an abstract cultural structure that also prevails beneath and above the practices of human agents. It understands memory as a collectively, institutionally and culturally formulated deep structure, which may reach back hundreds of years. Memory mediums - such as different sites of memory, art and literature - and the mediation of memory have been important research subjects of memory studies (Erll, 2011; Hamilton \& Shopes, 2008, pp. ix-x). In other words, the essential difference between these two research fields can be characterized in terms of scale: oral history research focuses on personal and private memory, whereas memory studies concentrates on public and collective memory.

Generally these two fields studying the cultural meanings given to the past, memory studies and oral history research, have been relatively distant from each 
other, owing partly to their different historiographical trails (Hamilton \& Shopes, 2008, pp. x-xii; Heimo, 2010, pp. 37-38; Erll, 2011, pp. 53-54), albeit exceptions can be found (e.g. Hamilton \& Shopes (eds.), 2008; Koresaar \& Joesalu, 2016; Kuusisto-Arponen \& Savolainen, 2016; Heimo, 2016). Despite the many differences between these two fields of research, however, they share interest in the present on the role of the past. Both of these fields focus on why, how and when something is or is not remembered. Nevertheless, as Hamilton and Shopes have argued, the relationship between the person who does the remembering and the public expressions of memory or the group's memory has not yet gained enough scholarly attention (Hamilton \& Shopes, 2008, p. x). Their suggestion is to bridge the gap between oral history research and memory studies and to analyze the relationship between individual and public articulations of memory (Hamilton \& Shopes, 2008, pp. xiv-xv; see also Thomson, 1996; Lorenz, 1999; Zur, 1999; Sturken, 2001). Building on this, in my article I analyze the relationship between individual and public memory by focusing on silence and the breaching of silence related to the internment of German and Hungarian civilians in Finland.

Despite the disconnection between oral history research and memory studies, these two fields explain the reasons behind forgetting and silence in a rather similar way. According to van Vree, common patterns of explaining social forgetting and silence are the "paradigm of hegemonic memory" and the "paradigm of traumatic memory" (van Vree, 2013). From the framework of the paradigm of hegemonic memory, social forgetting and silence are results of political repression or signs of more discrete cultural hegemony (van Vree, 2013, pp. 2-3; see also Zur, 1999, pp. 50-51; Lorenz, 1999; Rigney, 2005, p. 13). Conversely, from the framework of the paradigm of traumatic memory, social forgetting is seen as a psychological phenomenon, as a consequence of devastating experiences related to violence or otherwise repressive acts (van Vree 2013, pp. 3-4; see also Zur, 1999, pp. 50-51; Douglas \& Vogler, 2003). Van Vree argues that these two rather mechanical patterns do not suffice to understand the complexities related to silence. This is also true in the case of internment in Finland. Indeed, unlike in case of many other investigations of social forgetting and silence (e.g. Lorenz, 1999; Zur, 1999; Thomson, 1996), silence related to internment cannot be considered as a result of political repression, intentional suppression of memory, or of a fundamental discord between private and public memory. For a long time, the event of internment was too absent from the public consciousness for even to be forcibly or consciously silenced about. 
These two patterns of explaining silence and social forgetting, namely the trauma and hegemony explanation, also adhere to the Western understanding of forgetting as something negative and remembering as positive (Brockmeier, 2002, p. 16; also Connerton, 2008). Furthermore, silence does not often mean forgetting, but rather, it is a "socially constructed space in which and about which subjects and words normally used in everyday life are not spoken" (Winter, 2010, p. 4). My aim in this article is to analyze reasons behind silence and rupturing of silence from neutral viewpoint without making value judgements on remembering or forgetting. Moreover, I understand the nature of both individual and cultural memory as dynamic, processual, and mediated, not so much preserving. Memory takes its forms in representations through which past is made present (Rothberg 2009, p. 3; Huyssen, 1995, p. 2) and silence as well as forgetting is naturally a part of this process. Furthermore, in the case of my primary research materials, reminiscing takes place in an interview context. Hence, remembering and narrating are collaborative and interactional efforts of the interviewee and myself (Frisch, 1990; Portelli, 1997). This also means that in the interview situation, the past is told in the present and thus it is subject to the attention of the assumed or imagined audience at the moment of telling (Mishler, 2006; Minister, 1991).

Van Vree recommends Goffman's classic and widely applied (and disputed) concept of "framing" as one solution to grasp the communicative nature of memory and the reasons behind silence or social forgetting (van Vree, 2013, pp. 5, 7-10). According to Goffman, frames are cognitive structures, schemes of interpretation, governing the reception and representation of reality and experiences. Frames - which can be described as narratives or values - are crucial in the production of meaning and the sorting out of information. Frames are part of communication, and without them experiences or memories could not be communicated, let alone interpreted (Goffman, 1974). I find the concept of frame applicable in my research as well, because unlike for example the concepts of masterand counter narrative (see Bamberg, 2005; Bamberg \& Andrews, 2004 (eds.)), which tend to imply to the presence of competing interpretations, as a term frame is seemingly more neutral. I understand frames as not only constraints but also resources of telling, which are used by the interviewee for communicating certain meanings and narratives.

However, I suggest that in addition to the concept of frame, the concept of "tellability" is relevant in order to analyze and understand silence and the breaking of silence related to internment. Originally developed in conversational narrative 
analysis, tellability is a concept that refers to qualities of the story and the storytelling context that make a story worth telling (e.g. Labov, 1972; Sacks, 1992). Tellability requires that the storyteller considers an event to be surprising or important enough to be reported in a certain communicative context. Scholars of narrative and conversation have had different views on the main criteria of a tellable story. For example, Bruner notes that tellability requires the story to discuss "how an implicit canonical script has been breached, violated, or deviated from" (Bruner, 1991, pp. 11-12; Ochs \& Capps, 2001). Recent discussion on tellability has moved from story and content to viewing tellability as a property of different contexts of telling as well. Many scholars have analyzed the different context-, culture- and genre-specific variables that affect tellability (e.g. Shuman, 2012). Ochs and Capps have emphasized how tellability is negotiated and collaboratively constructed in storytelling performance (Ochs \& Capps, 2001; see also Sacks, 1992). Ochs and Capps also use the term "tellability" to introduce the concept of untold stories, which are stories that cannot be told due to different cognitive, psychological or cultural reasons (Ochs \& Capps, 2001, p. 257). Furthermore, Norrick discusses "the dark side of tellability" by analyzing stories that are not told. Some stories do not fulfill the criteria of tellability because they are too insignificant to reach the threshold of tellability in a certain context, while others are personal, frightening or too uncomfortable in other ways, such that they go beyond the range of what is tellable (Norrick, 2005, p. 327; Goldstein \& Shuman, 2012, pp. 119-120). Shuman has also pointed out that tellability is sometimes challenged by the unacceptability of the event (Shuman, 2006, p. 159).

\section{Explaining the silence}

Next I will elaborate on reasons that compromised the tellability of the story of internment and, thus, promoted silence. During and after wartime, experiences related to crisis and the war were more or less a norm in society. In the case of the internment in Finland, the silence stemmed partly from its unremarkability and normalcy in the post-war context. Many of my interviewees explained their silence, which lasted for decades, by saying that there was actually nothing to tell and that the overall experience of the post-war life overshadowed the experience of the internment:

Interviewer: Did you ever talk about the internment with your sister? 
Interviewee: No, no.

Interviewer: So it was not that kind of a conversation topic.

Interviewee: No, it was not. During that time, life was just barer and harder and it [the internment experience] was just left behind. (Interview 7/28/2015; male, b. 1942)

[Interviewer: Puhuitteko te koskaan teidän siskon kanssa tästä internointiasiasta? Haastateltava: Ei, ei.

Interviewer: Et se ei ollu semmonen keskustelunaihe.

Haastateltava: Ei ollu joo. Se oli vaan siihen aikaa elämä oli muutenkin karumpaa ja kovempaa ja se [internointikokemus] jäi vaan niinku taakse.]

In addition to being explanations for not having told, this and similar accounts point to the fact that for a long time, the story of internment lacked the criteria of a tellable event because it was considered so normal during wartime. Indeed, the story of internment did not have any special content or dramatic features that would have made it worthy, not to mention newsworthy, of telling. Many of my interviewees explained their silence to me by stating that it was rather normal to have lost something because of the war. These comments, which situate internment in relation to other wartime events, allude first of all to the interview situation. They can be understood as contextual information given to an interviewer who belonged to a different generation. Interviewees did not want to mislead the young interviewer (i.e. me) with overdramatic interpretations of internment experiences.

Many interviewees also explained the silence related to the internment by comparing their experiences to other wartime events and by insinuating how things could have also been much worse for them. These statements reflect interviewees' ethical responsibility towards other victims of war. Indeed, the internment occurred right after the dramatic years of the war. In Finland, the war led to the evacuation and resettlement of over 400,000 Karelian evacuees and made the status of Finland's independence fragile (see Savolainen, 2017). In order to achieve peace with the Soviet Union and maintain independence, Finland accepted the harsh terms of the armistice agreement. The internment of German and Hungarian citizens staying in Finland was only one of the conditions for peace. Difficult conditions were accepted in Finland without large-scale resistance. The popular opinion was that Finland had no other choice than to do what the Soviet Union demanded and that everybody had to sacrifice something for 
independence. Considering this, it is true that the internment was a rather insignificant event, notwithstanding the individual lives of the 470 internees. Hence, the event was not worthy of telling in post-war Finland.

Another reason that compromised the tellability of the story of internment was its lack of proper kinds of narrative agents possessing proper qualities. Namely, both the right kind of victims and the right kind of perpetrators were missing from the story. Based on my interviews, "the perpetrator" of the narrative of internment was for a long time the Soviet Control Committee, which supervised that Finland did what had been agreed on in the peace agreement. Therefore, the demands of the Control Committee could not be considered as peculiarly oppressive or wrong. A distinct group of victims was also missing from the story. Internees did not consider themselves as a distinct group of victims, because several other groups of Finns suffered from the war and its consequences in the post-war years. The perpetrator in the story, the Soviet Control Committee, not only persecuted those who were interned, but all Finns generally.

Growing interest in the Holocaust in the post-war decades and the many popular representations of Nazi concentration camps and the victims of the Holocaust also affected the formulation of the frame for the interpretation and representation of victims and perpetrators of war on a more general level. (On the holocaust memory, see e.g. Levy \& Sznaider, 2002; Stier, 2003; Rothberg, 2009.) Based on my interviews, the horrifying image of the Nazi concentration camp came to represent the general idea of detention camps. Another image of detention camps present in Western popular consciousness, although not as endemic and wideranging as the image of Nazi concentration camps, was based on the information about the Gulags in the Soviet Union (see e.g. Toker, 2000; Adler, 2002). These ideas became the basic constituents of the frame for detention camps for civilians. Fairly undramatic experiences of internment in Finland did not adhere to this frame very well. Thus, the disparity between the existing frame of detention camps and the experience of internees compromised the tellability of the internment experience and promoted silence. The prevalence of this kind of frame for detention camp experiences is present also in my interview materials, even though it did not match with interviewees' experiences. For example, even though I did not explicitly ask about the conditions of the internment camp, interviewees often stated that they were not tortured or mistreated in any way. By underlining that they were not mistreated, ex-internees not only explained their experiences to me, but they also referred to the prevailing frame for understanding detention camps as 
places of torture, torment and death (see also Schiffrin 2001, pp. 515-516):

Interviewer: Have you ever discussed about the internment with Germans? Did they have an idea that this kind of thing happened in Finland?

Interviewee: No, it has been silenced. I think that this was not talked about at all because of the atrocities done by the Germans, so that this is an insignificant matter. I have understood, and heard from my mother and later from the others, that there was no suffering, and there were no punishments, except if you escaped. It is wrong to draw a parallel with some kind of concentration camp or something else, as the conditions were fairly decent for the conditions of that time. The food was bad, but I think that it was no better on the outside at that time... (Interview 4/1/2015; male, b. 1943)

[Interviewer: Onko koskaan tullut puhetta internoinnista saksalaisten kanssa, et onko siellä käsitystä et tämmöstä on Suomessa tapahtunut?

Interviewee: Ei, se on vaiettu. Mä luulen et siit ei oo puhuttu ollenkaan johtuen tästä Saksan hirmuteoista, et täähän on vähäpätöinen asia. Mä oon ymmärtäny, sekä kuullu äidiltäni, että nyt myöhemmin sitten muilta, ni ei siinä kärsitty, eikä siinä ollu rangaistuksia, muuta kun jos karkas, mutta väärin sanoo, rinnastaa johonkin keskitysleiriin tai johonkin muuhun, et kylhän tos oli sillosis olosuhteissa niinku ihan asialliset olosuhteet. Ruoka oli kehnoo mutta mä luulen, et ei siihen aikaan siviilissäkään...]

Based on my analysis, stigma potential related to the German background ${ }^{6}$ are also significant factors behind the silence. In the standard interpretation of the Second World War, Germans were placed on the guilty side. Also in Finland, the post-war political and ideological atmosphere made the story of internment untellable. In Finland, the attitude towards Germany was confused and tense, due to particular local reasons as well. In fact, after Finland had exited the Continuation War (in which it fought with Germany against the Soviet Union) in the summer of 1944, Finland fought the Lapland War against Germany, its former ally. In the Lapland War, Finland's goal was to evict German troops from the country. During this war, German troops ended up burning large areas of Lapland. Political changes and

${ }^{6}$ Interviewees with a Hungarian background did not describe shame related to this. I asked one of the interviewees about the general attitude towards his Hungarian background and he said that it was rather positive, because of the (linguistic) kinship between Finns and Hungarians. 
events also affected the public discussion of Finnish-German relations during the war, even though general ethos in Finland towards Germany and Germans remained relatively positive also in post-war years (see Kivimäki 2012, p. 492). For many of my interviewees, one result of the Second World War was that it turned their German background into a negative stigma. It was something that they felt ashamed or guilty about. According to many interview accounts, a German background was something that they did not want to highlight:

Interviewee: But after that [liberation], life was completely different. Totally different, so that I felt myself very lonely because others of the same age, the schoolmates, it was as if, it [life] did not exist anymore. Like, you had to change yourself into an entirely different [person], to leave that... Then also even my father told us: "Denkt Sie, auf der Straße nicht Deutsch sprecht" [do not speak German on the streets], so that I got, I had kind of feelings of guilt that this Germanness is something bad. (Interview 1/21/2016; female, b. 1926)

[Interviewee: Mut sitten sen [vapautumisen] jälkeenhän elämä oli ihan erilainen. Täysin erilainen, että mä tunsin itseni hyvin yksinäiseks koska ne saman ikäiset mitä oli koulukavereita, se oli niin kun, ei ollu enää olemassa. Että piti niinkuin muuttaa itsensä niinkun kokonaan erilaiseks, jättää se... Mun isä vielä sanoi sitten meille: "Denkt Sie, auf der Strasse nicht Deutsch sprecht," että siin tuli mulle tuli, mä sain semmosia [tauko puheessa] syyllisyyden tunteita, että tää saksalaisuus oli jotain huonoa.]

The interviewee describes the liberation from the internment camp as a point of change. After the camp, her life had changed and the ways in which she understood herself as a person with a German background had changed. This change was not a positive one, as she learned that the German background had turned into a negative quality. For her, this cultural and political change also meant changing herself and concealing her Germanness. Indeed, many of my interviewees explicitly and implicitly implied that communication about the internment experience may have raised questions about the reason behind the internment, which was having German citizenship. For many, therefore, silence about the internment also meant keeping silent about their German background. Considering this historical context, it is also understandable why internees did not consider themselves as victims. They were not tortured or mistreated. Instead, they were German citizens, and because Germany had lost the war, it was also natural that they as Germans had to live with and suffer the consequences of that. Even 
though their ties to Nazi Germany were thin, they were still Germans. In a way, they found themselves guilty of internment just by being Germans. Based on my interviews, experiences of shame and guilt compromised the tellability of the story of internment and supported silence about related experiences.

The internment of German and Hungarian citizens was not publicly discussed in Finland. As a consequence, hardly anyone outside of close relatives and the acquaintances of internees knew anything about the matter. Due to this lack of information, there was also a great risk for internees to be misinterpreted or accused of lying if they told about the internment. For example, some of my interviewees told me that they felt that the internment was shameful because normally only criminals were imprisoned. Based on my research materials, it seems that eventually the silence itself made discussion and communication of personal experiences impossible. As nobody but the internees themselves knew about the internment, and as the experience could not be represented or interpreted in terms of the existing frames, it eventually became an untellable event that internees did not have the ability or need to communicate to others outside their close private circle.

\section{Rupturing of the silence}

The largely-forgotten event of internment was brought to the awareness of the general public in 2003 by TV-documentary of Mikko Määttälä. In addition, the film revealed that Finnish officials, not the Soviet Control Committee, decided to intern Finnish-born women and children. The film claimed that these people were incarcerated for 1.5 years out of court because Finnish officials tried to match the number of internees with the official statistics of Germans living in Finland. This claim was carefully supported by the historian Niklas Jensen-Eriksen (2009). The reason why the statistics did not match the reality was that when Finland exited the war and strove to achieve peace with the Soviet Union and the Allied forces, it had to end its collaboration with Germany. Due to this, many of the German citizens living in Finland left for abroad, mainly to Germany and Sweden, and the actual number of Germans in Finland in 1944 was significantly smaller than the number found in the pre-war statistics. Thus, in 1944, Finnish officials did not manage to gather enough Germans into the internment camps; therefore, they decided to also intern Finnish-born women, children, and sick and elderly persons, even though 
Soviet Control Committee never demanded it (see Jensen-Eriksen, 2009). My interviewees generally described this decision as a cowardly and pathetic act, something far even from the "normal abnormal" acts of the wartime.

The documentary film set in motion a process of breaking the silence and becoming aware of the historical event of internment. This process included journalistic articles, which were often based on witness testimonies and a book authored by Mikko Määttälä (Määttälä, 2011), which was also partly based on the testimonies of ex-internees. Also The National Archives launched a research project in 2008, and the main objective of the initiative was to study the status and conditions of the internees in order to prepare compensatory legislation (Westerlund (ed.), 2010, p. 7; see also Jensen-Eriksen, 2009). After the documentary was broadcast, internees as well started to play an active part on their behalf. For example, they established an unofficial organization and appointed an unofficial committee of five persons, which started to campaign for a law demanding compensation. Eventually, after almost ten years of lobbying, this process led to the passing of a law supporting monetary compensation. The compensation law came into effect on September 1, 2014. According to the law, those interned persons who were under 18 years of age, Finnish citizens, or adult children of Finnish citizens were entitled to compensation of 3000 euros (Finlex Data Bank, 2014). The group entitled to this compensation consisted of approximately 50 elderly persons.

The revelation of the documentary is the most important reason why the silence surrounding the topic was eventually broken. Based on my analysis, I argue that this new information actually managed to end the silence and begin the process of construction of memory of the internment because it addressed all of the major reasons behind the silence, which I discussed above. First, the new information questioned the relative normality of the internment by shedding light on the shady reasons behind the Finnish officials' decision behind the interment. The information proved that even by wartime standards, the internment of children and Finnish-born women was unjustified. This information also taught the ex-internees to think of their internment and their past in a new way, not as one of the many unpleasant but justifiable events of wartime, but as pure injustice:

Interviewer: When you were in the camp, do you remember if you were rationalizing the decision to put German-born people and their spouses and 
children into camps? Or did you have an experience of injustice or were there these kinds of things at all?

Interviewee: Well, I don't believe that back then [there were experiences of injustice]. Because we knew... As much as we knew, it was a part of the peace agreement, so it was not like Finland's [decision]. And we also knew, or adults knew, that these kinds of things happen in other places, too, that also Finns were interned in other places, so I do not believe that it... And we were led to believe until 2003 and the broadcasting of this Eyewitness ${ }^{7}$ thing [the documentary] that the internment of women and children was also the Soviet Union's [decision], that the demand came from there. So, even when I was already was an adult, I also always defended Finland. At first we never spoke about this internment, but sometimes as an adult I maybe told to a good friend something, and then the friend maybe marveled "Oh, how terrible," and I remember that I had a standard answer: it was not Finland's fault. That they could not do anything about it and it was the Soviet Union that demanded that [internment]. So it was not until Mikko Määttälä made this [documentary], as a reporter he had now researched these papers, and it was not until then that this came up, that it was not the Soviet Union at all the whole time. (Interview 3/4/2015; female, b. 1933)

[Interviewer: sillon leirillä olo aikana niin muistatko sä, että sitä jotenkin olisi järkeilty sitä päätöstä sulkea leirille saksalais-syntyiset ihmiset ja heidän puolisot ja lapset? Vai oliko kokemusta epäoikeudenmukaisuudesta tai oliks tämmösiä ollenkaan?

Interviewee: No, en mä usko että sillon [olisi ollut epäoikeudenmukaisuuden kokemusta]. Sen takia että tota mehän tiesimme, niin paljon kun me tiesimme, että se oli osa tätä välirauhasopimusta, et se ei ollu niinkun Suomen [päätös] ja mehän tiesimme myöskin, tai aikuiset tiesivät, että tällasta sattuu muuallakin, että Suomalaisiakin oli internoituja muualla, että en mä usko, että se se... Sitten meidänhän annettiin uskoa ihan siihen asti kun 2003 kun kun tuli tää Silminnäkijä-juttu, niin että naisten ja lasten internoiminen oli myöskin tota Neuvostoliiton [päätös], et sieltä se vaatimus tuli. Että minäkin ni, ihan aikuisena vielä aina puolustin Suomea. Kun me, alussahan me ei koskaan puhuttu tästä internoimisesta, mutta sitten joskus aikuisena nyt kertoi ehkä jos jollain hyvälle ystävälle jotain, ja sitten ehkä päivitteli, että että "voi kauheeta sentään", ja mä

${ }^{7}$ Eyewitness [Silminnäkijä] is the name of the documentary series. 
muistan, että mulla oli ihan standardivastaus: että mutta ei se ollu Suomen vika. Että eihän eihän ne voinu mitään, et se oli Neuvostoliitto joka vaati sen [internoinnin]. Et se oli vasta sillon kun Mikko Määttälä teki tän [dokumentin], hänhän sanomalehtimiehenä nyt tutki sitten näitä papereitä ja et vasta sillon ilmeni tää, että se ei ollukkaan Neuvostoliitto, että koko tää aika.]

The excerpt above shows very clearly that even though I suggested that the interviewee reflect on her memories of feeling of injustice in the past, she refused to do that. Instead, she underlined that the feeling of injustice arose only after the information related to the Finnish officials' role in the decision to intern children had come out. She stressed that before the documentary came out, she thought that the interment was based on legitimate reasons. Not wanting to generally question Finland's need to deliver the conditions of the armistice agreement, instead she appealed to the new information about the active role of Finland in deciding who was interned. This shows that the documentary film indeed had a significant role in making the story of internment tellable by creating a frame for telling the story. This frame includes surprise, collapse of beliefs, and newly defined agents of the story. In addition, the documentary film and the new information became a central part of the story of internment.

Second, the new information brought the experiences of internment closer to the existing frames of understanding war experiences, which relate to the oppositional agential position between victims and perpetrators. This new information was presented in the media (for example, in newspaper articles) as hidden information that was now exposed. Even though the information was hardly kept in secret deliberately, telling about it after 60 years of silence supported the interpretation of the internment as a more or less deliberate injustice. This increased the tellability of the story of internment by closening it with the existing frames of understanding and representing the war events and adding an element of exposure and surprise to it. This newly emerging interpretation of the story of internment also imposed the role of perpetrators on Finnish officials, while the journalistic articles included testimonies and comments of the ex-internees; the new information in a way validated the testimonies of ex-internees as they gained the position of victims.

Third, by creating two oppositional positions of the perpetrators and the victims, the new information also decreased the shame, guilt and stigma that had earlier caused silence and made the experience of internment untellable. Ex-internees 
came to have the clear position of victims, which encouraged them to formulate their testimonies. They no longer needed to feel the shame, guilt and stigma, or fear of misinterpretations that the previous lack of general knowledge of the event generated. In other words, the story of internment became tellable. The memory of the internment also gained a new story, which included discussions about becoming aware of the injustice and demanding justice:

Interviewer: So, how did it feel when you found out about this [Finnish official's role in making the internment decision]?

Interviewee: Well, look, it sure felt bad. Oh my God, it felt bad. I did like think then when... Then right after that, this started with us, we got to know, so this started from the program of Mikko Määttälä. I immediately called to the office of this [journalist] that like, this is a wonderful thing that you are bringing this out, but there would be a lot more to write about this, and the journalist said that Mikko Määttälä is the right person, that s/he [the journalist] is just a boss, that Mikko had made this. After that we contacted Mikko and then we organized a meeting in the building of the German congregation. I did not attend this first meeting, but the second one I did, and in the second meeting this committee [that promoted the compensatory law] was established. There were altogether six of us, six members, but two stayed away [...] And until last year we tried to wrestle [for the promotion of the compensatory law], so 11 years.

(Interview 3/23/2015; male, b. 1939)

[Interviewer: Miten tota, miltä se tuntu ku te saitte tietää tän näin [Suomen viranomaisten osuuden internointipäätökseen]?

Interviewee: No kyllä tuntu kuule pahalta, voi hyvänen aika se tuntu pahalta. Kyllä mä sillon niinku aattelin kun... Sittenhän ihan kohta sen jälkeen, tää lähti meillä, me saatiin tietää, niin lähti siitä Mikko Määttälän ohjelmasta. Mä soitin heti sinne toimitukseen tälle [toimittajalle] et noin, tää on hieno juttu, et te tuotte tän esille, mutta tästä olis paljon paljon enempi kirjoitettavaa, ni se sano että Mikko Määttälä on oikee henkilö, että hän on vaan niinku tää pomo, että Mikko on tän tehny. Sitte me otettiin Mikkoon yhteyttä ja sitte tuol saksalaisen seurakunnan tiloissa järjestettiin tämmönen kokous, mä en ollu siinä kokouksessa, siinä ensimmäisessä kokouksessa, mutta toisessa olin sitte jo, siinä toisessa kokouksessa perustettiin tää työryhmä [joka ajoi korvauslakia]. Ja meit oli kaiken kaikkiaan kuus, kuus jäsentä, mutta niistä kuudesta jäsenestä kaks putos pois [...] Ja me sitte viime vuoteen asti koitettiin painia [korvauslain edistämiseksi] eli 11 vuotta.] 


\section{Conclusions}

In this article, I used the concept of tellability to analyze the oral history interviews of ex-internees in relation to the public discussion of internment. I examined why and how the historical event and experience of internment was untellable or silenced in the past, and why and how it became tellable later. I also identified the frames and the lack of frames involved in defining the tellability of the story. In the case of the memory of the internment of German and Hungarian citizens in Finland, the documentary film and new information on the Finnish officials' role in deciding on the incarceration of Finnish-born women and children were crucial for the story of internment to become tellable. The new information addressed all of the issues that had earlier compromised tellability of the story and promoted silence around the internment, in public and sometimes also in personal and private spheres of life. First, the new information questioned the normalcy of the internment and proved that even by wartime standards, the internment of children and Finnish-born women was unjustified. Second, it brought the experiences of internment closer to existing frames of understanding war experiences, which relate to the oppositional position between victims and perpetrators. Third, the new information also decreased the shame, guilt and stigma (often related to having a German background) of the ex-internees.

The case I presented in this article also indicates that the relationship between the private and public dimensions of memory is mutually productive. The interplay between public and personal memory has a vital role in the construction of memory. Indeed, the public discussion of internment was strongly formulated by personal memories and testimonies, which were included in newspaper articles, books and the documentary in addition to information gathered from other sources. In this process of building a public memory of the internment, the personal memories of ex-internees were integrated into the public discussion of the internment. Hence, life stories and eyewitness testimonies affected the public memory and vice versa (see also Sturken, 2001, p. 34). The documentary film by Mikko Määttälä initiated a process of construction of the memory of internment. The knowledge about the injustice was central in terms of the construction of memory. In the process, it was revealed that Finnish officials were behind the internment instead of the Soviet Union. Hence, the reason behind the internment was not a demand of the peace agreement, but instead a decision of bureaucrats. 
On the public level, knowledge about the injustice led to the passing of the law of compensation in 2014. On a private level, this knowledge gave a valid reason and proper frame for ex-internees to share their experiences and memories; in other words, it made the story of internment tellable. By comparing the interviewees' descriptions of the reasons behind the silence with the descriptions of the rupturing of the silence, the public discussion (which also included personal testimonies) created the frame for the story and promoted its tellability.

My analysis supports the ideas of many narrative scholars on the contextdependent nature of tellability. As Amy Shuman has emphasized, tellability is a property of contexts, and as such it does not belong either to narrators or to stories (Shuman, 2012, p. 129, 149; Ochs \& Capps, 2001; Norrick, 2005). My analysis also shows that in addition to the communication context of the storytelling event, wider sociohistorical contexts also affected the tellability of the story. My analysis suggests that the analytical concepts of tellability and frame are useful in understanding the dynamics between personal and public memory, and in understanding why some experiences and events of the past become narrated and remembered while others are forgotten or silenced. Ultimately, methodologies of narrative analysis have the potential to bring the fields of oral history research and memory studies into fruitful dialogue. In constructing the memory of internment, the public and personal representations of memory are mutually dependent and are both very much connected to the questions of tellability and frame.

\section{Research materials}

The 26 interviews were conducted by the author (March 4, 2015 - July 29, 2016). The interview recordings are in the trust of the author and will be archived at the Finnish Literature Society's Archives in Helsinki, Finland.

\section{Acknowledgements}

I am grateful to the Finnish Cultural Foundation and the Academy of Finland project SA 294292 for funding my research.

\section{References}


Abrams, L. (2010). Oral History Theory. New York: Routledge.Adler, N. (2002). The Gulag Survivor. Beyond the Soviet System. New Brunswick \& London: Transaction Publishers.

Bamberg, M. (2005). Master Narrative. In D. Herman, M. Jahn \& M-L. Ryan (Eds.), Routledge Encyclopedia of Narrative Theory. London: Routledge.

Bamberg, M. \& Andrews, M. (Eds.) (2004). Considering Counter Narratives. Narrating, Resisting, Making Sense. Amsterdam: John Benjamins Publishing. doi: 10.1075/sin.4

Brockmeier, J. (2002). Remembering and Forgetting: Narrative as Cultural Memory. Culture \& Psychology, 8(1), 15-43. doi: 10.1177/1354067X0281002

Bruner, J. (1991). The Narrative Construction of Reality. Critical Inquiry, 18, 1-21. doi: $10.1086 / 448619$

Connerton, P. (2008). Seven Types of Forgetting. Memory Studies, 1(1), 59-71.

Douglas, A. \& Vogler, T. (Eds.) (2003). Witness and Memory: The Discourse of Trauma. New York: Routledge.

Erll, A. (2011). Memory in Culture. London: Palgrave Macmillan.

Finlex Data Bank. (2014). Laki korvauksesta eräille internoiduille siviilihenkilöille. Retrieved from: http://www.finlex.fi/fi/laki/alkup/2014/20140510

Frisch, M. (1990). A Shared Authority: Essays on the Craft and Meaning in Oral and Public History. Albany: State University of New York Press.

Goffman, E. (1974). Frame Analysis: An Essay on the Organization of Experience. London: Harper and Row.

Goldstein, D. \& Shuman, A. (2012). The Stigmatized Vernacular: Where Reflexivity Meets Untellability. Journal of Folklore Research, 49(2), 113-126.

Hamilton, P. \& Shopes, L. (2008). Introduction: Building partnership between oral history and memory studies. In P. Hamilton \& L. Shopes (Eds.), Oral History and Public Memories (pp. vii-xvii). Philadelphia: Temple University Press.

Heimo, A. (2010). Kapina Sammatissa. Vuoden 1918 paikalliset tulkinnat osana historian yhteiskunnallisen rakentamuisen prosessia. Helsinki: Finnish Literature Society.

Heimo, A. (2016). Nordic-Baltic oral history on the move. Oral History, 44(2), 37-46.

Huyssen, A. (1995). Twilight Memories: Marking Time in a Culture of Amnesia. New York: Routledge.

Jensen-Eriksen, N. (2000). Välirauhan väliinputoajat. Suomessa asuneet saksalaiset Valpon varjossa 1944-1947. In H. Saarinen, M. Peltonen \& K. Multamäki (Eds.), “Se rakkain kotipolku” - Erkki Kouri ja yleinen historia (pp. 333-354). Helsingin yliopiston julkaisuja 15. Helsinki: Helsingin yliopisto. 
Jensen-Eriksen, N. (2009). Saksan ja Unkarin kansalaisten sekä heidän puolisoidensa internointi 1944-1947. Helsinki: Kansallisarkisto.

Jensen-Eriksen, N. (2010). Valpon internointileirit ja niiden asukkaiden polittinen valvonta vuosina 1944-1947. In L. Westerlund (Ed.), Sotatapahtumia, internointeja ja siirto sodanjälkeisiin oloihin. Kansallisarkiston artikkelikirja / Wars, Internees and the Transition to the Postwar Era. A Book of Articles from the National Archives of Finland (pp. 103-134). Helsinki: The National Archives of Finland. Available online: http://www.arkisto.fi/uploads/Palvelut/ Julkaisut/Internoidut_Naytto.pdf (accessed 4/17/2016).

Khevniuk, O. V. (2004). The History of the Gulag: From Collectivization to the Great Terror. New Haven: Yale University Press.

Kivimäki, V. (2012). Between Defeat and Victory: Finnish memory culture of the Second World War. Scandinavian Journal of History, 37(4), 482-504. doi: 10.1080/03468755.2012.680178

Koresaar, E. \& Joesalu, K. (2016). Mnemonic turn, post-Soviet memories and "memory shifts" in Estonia. Oral History, 44(2), 47-58.

Kuusisto-Arponen, A.-K. \& Savolainen, U. (2016). The interplay of memory and matter: Narratives of Former Finnish Karelian child evacuees. Oral History, 44(2), 59-68.

Labov, W. (1972). Language in the inner city. Philadelphia: University of Pennsylvania Press.

Levy, D. \& Sznaider, N. (2002). Memory Unbound: The Holocaust and the Formation of Cosmopolitan Memory. European Journal of Social Theory, 5(1), 87-106. doi: 10.1177/1368431002005001002

Lorenz, F. (1999). The Unending War. Social Myth, Individual Memory and the Malvinas (Transl. Ozón, G.). In K. L. Rogers \& S. Leydesdorff \& G. Dawson (Eds.), Trauma. Life Stories of Survivors (pp. 95-112). New Brunswick \& London: Transaction Publishers.

Minister, K. (1991). A Feminist Frame for the Oral History Interview. In S. Berger Gluck \& D. Patai (Eds.), Women's Words: the Feminist Practice of Oral History (pp. 27-42). New York: Routledge.

Mishler, E. G. (2006). Narrative and Identity: The Double Arrow of Time. In A. De Fina, D. Shiffrin \& M. Bamberg (Eds.), Discourse and Identity (pp. 30-47). Cambridge: Cambridge University Press. doi:10.1017/CBO9780511584459.003

Määttälä, M. (2011). Vihollisina vangitut. Internointileirit neuvostosuhteiden välikappaleina 19441947. Jyväskylä: Atena Kustannus Oy.

Norrick, Neal R. (2005). The Dark Side of Tellability. Narrative Inquiry, 15(2), 323-43. doi: 10.1075/ni.15.2.07nor

Ochs, E. \& Capps, L. (2001). Living Narrative: Creating Lives in Everyday Storytelling. Cambridge: Cambridge UP.

Portelli, A. (1997). The battle of Valle Giulia: oral history and the art of dialogue. Madison: University 
of Wisconsin Press.

Portelli, A. (1998). What Makes Oral History Different? In R. Perks \& A. Thompson (Eds.), The Oral History Reader (pp. 63-74). London \& New York: Routledge.

Rigney, A. (2005). Plenitude, Scarcity and the Circulation of Cultural Memory. Journal of European Studies, 35, 209-226. doi: 10.1177/0047244105051158

Robertson, D. (2004). A Dictionary of Human Rights. London \& New York: Taylor \& Francis Group.

Rothberg, M. (2009). Multidirectional Memory: Remembering the Holocaust in the Age of Decolonization. Stanford California: Stanford University Press.

Sacks, H. (1992). Lectures on Conversation. Oxford: Blackwell.

Savolainen, U. (2017). The Return. Intertextuality of Reminiscing of Karelian Evacuees in Finland. The Journal of American Folklore, 130(516), 166-192. doi: 10.5406/jamerfolk.130.516.0166

Schiffrin, D. (2001). Language and Public Memorial: ‘America's Concentration Camps'. Discourse \& Society, 12(4), 505-534. doi: 10.1177/0957926501012004005

Shuman, A. (2006). Entitlement and Empathy in Personal Narrative. Narrative Inquiry, 16(1), 157164. doi:10.1075/ni.16.1.19shu

Shuman, A. (2012). Exploring Narrative Interaction in Multiple Contexts. In J. A. Holstein \& J. F. Gubrium (Eds.), Varieties of Narrative Analysis (pp. 125-150). Thousand Oaks: Sage. doi: $10.4135 / 9781506335117 . n 7$

Smith, P. (1995). Democracy on Trial: The Japanese American Evacuation and Relocation in World War II. New York: Simon \& Schuster.

Stier, O. B. (2003). Committed to Memory: Cultural Mediation of the Holocaust. Amherst: University of Massachusetts Press.

Sturken, M. (2001). Absent Images of Memory: Remembering and Reenacting the Japanese Internment. In T. Fujitani \& G. M. White \& L. Yoneyama (Eds.), Perilous Memories: The Asia Pacific War(s) (pp. 34-49). Durham \& London: Duke University Press.doi: 10.1215/9780822381051-002

Thomson, A. (1996). Anzac Memories. Putting Popular Memory Theory into Practice in Australia. In R. Perks \& A. Thomson (Eds.), The Oral History Reader (pp. 300-310). New York: Routledge.

Toker, L. (2000). Return from the Archipelago. Narratives of Gulag Survivors. Bloomington \& Indianapolis: Indiana University press.

Uhlenius, P. (2010). Internoitujen muistot. Muistelijoiden kokemuskuvan peruspiirteitä. In L. Westerlund (Ed.), Sotatapahtumia, internointeja ja siirto sodanjälkeisiin oloihin. Kansallisarkiston artikkelikirja / Wars, Internees and the Transition to the Postwar Era. A Book of Articles from the National Archives of Finland (pp. 404-427). Helsinki: The National Archives of Finland. Available 
online: http://www.arkisto.fi/uploads/Palvelut/Julkaisut/ Internoidut_Naytto.pdf (accessed 4/17/2016).

van Vree, F. (2013). Absent Memories. Cultural analysis, 12, 1-17.Westerlund, L. (Ed.) (2008a).

Sotavangit ja internoidut. Kansallisarkiston artikkelikirja / Prisoner

of War and Internees. A Book of Articles by the National Archives. Helsinki: The National Archives of Finland. Available online: http://www.arkisto.fi/uploads/Palvelut/Julkaisut/

SOTAVANGIT\%20JA\%20INTERNOIDUT_WEB.pdf (accessed 4/22/2016).

Westerlund, L. (2008b). Internment and deportation in WWI and WWII. A comparative study with a special survey of the situation in Finland. In L. Westerlund (Ed.), Sotavangit ja internoidut.

Kansallisarkiston artikkelikirja / Prisoner of War and Internees. A Book of Articles by the National Archives (pp. 352-397). Helsinki: The National Archives of Finland. Available online:

http://www.arkisto.fi/uploads/Palvelut/Julkaisut/SOTAVANGIT\%20JA\%20

INTERNOIDUT_WEB.pdf (accessed 4/22/2016).

Westerlund, L. (Ed.) (2010). Sotatapahtumia, internointeja ja siirto sodanjälkeisiin oloihin. Kansallisarkiston artikkelikirja / Wars, Internees and the Transition to the Postwar Era. A Book of Articles from the National Archives of Finland. Helsinki: The National Archives of Finland. Available online: http://www.arkisto.fi/uploads/Palvelut/Julkaisut/Internoidut_Naytto.pdf (accessed 4/17/2016).

Winter, J. (2010). Thinking about Silence. In E. Ben-Ze'ev \& R. Ginio \& J. Winter (Eds.), Shadows of War. A Social History of Silence in the Twentieth Century (pp. 3-31). New York: Cambridge

University Press. doi: 10.1017/CBO9780511676178.002

Zur, J. (1999). Remembering and Forgetting: Guatemalan War Widows' Forbidden Memories. In K. L. Rogers, S. Leydesdorff \& G. Dawson (Eds.), Trauma. Life Stories of Survivors (pp. 45- 59). New Brunswick \& London: Transaction Publishers.

\section{Author's address}

Ulla Savolainen

Department of Philosophy, History, Culture and Art Studies University of Helsinki

Folklore Studies / LIVINGMEMORIES-project

P.O. Box 59 Room C214, 00014 University of Helsinki, Finland

ulla.savolainen@helsinki.fi

https://tuhat.helsinki.fi/portal/en/person/uesavola 